\title{
Syntheses and Activities of Bioquinone Substances. I. Total Syntheses of Rhodoquinones
}

\author{
Yoshiaki Watanabe, Kiyoshi Nakajima, Teruya Seki, ${ }^{1 a)}$ \\ and HIKARU OzAWA ${ }^{1 b)}$ \\ Research Laboratory, Taisho Pharmaceutical Co., Ltd. ${ }^{1 a)}$ and \\ Pharmaceutical Institute, Tohoku University ${ }^{1 b)}$
}

(Received April 10, 1970)

\begin{abstract}
The total syntheses of naturally occurring rhodoquinone-9 $(I, n=9)$ and related compounds are described. The key intermediate, 2-halogeno-3-methoxy-6-methyl-1,4benzoquinone (VI), was easily obtained by 5 steps starting from $p$-cresol.

i) Reduction of VI and condensation of the resulting hydroquinone (IX) with solanesol in the presence of $\mathrm{BF}_{3}$.ether gave the nonaprenylated hydroquinone, which, on oxidation with $\mathrm{Ag}_{2} \mathrm{O}$, was transformed to 2-halogeno-3-methoxy-5-nonaprenyl-6methyl-1,4-benzoquinone (X). Treatment of $\mathrm{X}$ with $\mathrm{NaN}_{3}$ followed by reduction gave the azido hydroquinone from which rhodoquinone-9(I, n=9) was prepared through pyrolysis. ii) Reaction of VI with $\mathrm{NaN}_{3}$ followed by reduction gave the azido hydroquinone which was converted to rhodoquinone- $0(\mathrm{I}, n=0)$ by pyrolysis. iii) An attempt to obtain $(\mathrm{I}, n=0)$ by direct conversion of the $\mathrm{Br}$ atom of VI to amino group failed, but 2-bromo-3-amino-6-methyl-1,4-benzoquinone (VII) and the cyclohexenedione compound (VIII) were obtained.
\end{abstract}

In 1962, Glover and Threlfall2) isolated a compound from Rhodospirillum rubrum and termed this substance rhodoquinone. A little later, Folkers and coworkers ${ }^{3}$ ) reported that rhodoquinone should be related to the aminobenzoquinone structure by the spectral evidence and further established unambiguously its structure to be 2-amino-3-methoxy-5-decaprenyl6-methyl-1,4-benzoquinone (I, $n=10$ ) by the synthesis which was performed by ammonolysis of CoQ-10 (II, $n=10)$, ) applying preparative thin-layer chromatography (TLC) together with multiple development technique to separate the desired product from the 2-methoxy-3-amino isomer (isorhodoquinone) which formed concurrently in much larger amount than the desired isomer. The alternative synthetic method was also reported by Folkers, et al. ${ }^{5}$ ) which consisted in amination of 3-methoxy-5-decaprenyl-6-methyl-1,4-benzoquinone prepared by the following sequence: condensation of 3-methoxy-6-methyl-1,4-hydroquinone with decaprenyl alcohol followed by oxidation of the intermediate hydroquinone to desired 3-methoxy-5-decaprenyl6-methyl-1,4-benzoquinone which was separated from the reaction mixture contaminated mainly with the corresponding 2-decaprenylated and 2,5-didecaprenylated products. In this case, also, preparative TLC seemed to be an indispensable means of isolation and purification of the products.

Rhodoquinone-9 (I, $n=9$ ) was first isolated from Euglena gracilis ${ }^{6)}$ and recently from Ascaris lumbricoides var. suis by one of us (Ozawa), Natori, and coworkers. ${ }^{7-9)}$ In the latter work, the structural assignment was carried out by the syntheses which were succeeded by

1) Location: a) 34-1, Takata 3-Chome, Toshimaku, Tokyo; b) Aobayama, Sendai.

2) J. Glover and D.R. Threlfall, Biochem. J., 85, 14 (1962).

3) H.W. Moore and K. Folkers, J. Am. Chem. Soc., 87, 1409 (1965).

4) H.W. Moore and K. Folkers, J. Am. Chem. Soc., 88, 567 (1966).

5) G.D. Daves, Jr., J.J. Wilczynski, P. Friis, and K. Folkers, J. Am. Chem. Soc., 90, 5587 (1968).

6) R. Powls and F.W. Hemming, Phytochemistry, 5, 1235 (1966).

7) M. Sato and H. Ozawa, J. Biochemistry, 65, 861 (1969).

8) H. Ozawa, M. Sato, S. Natori, and H. Ogawa, Experientia, 25, 484 (1969).

9) H. Ogawa, S. Natori, M. Sato, and H. Ozawa, Tetrahedron Letters, 1969, 1969. 
<smiles>CCC(C)=CC=CC1=C(C)C(=O)C(OC)=C(N)C1=O</smiles>

I<smiles></smiles>

II ammonolysis of CoQ-9 (II, $n=9$ ) and also by amination of 3-methoxy-5-nonaprenyl-6-methyl-1,4benzoquinone isolated from $\mathrm{Pseu}$ domonas ovalis, respectively.

Rhodoquinone (I) is a relative of CoQ (II) which does play an important role in the electron transport system of living organism and is of biological interest. In view of the above situation, a novel synthesis of rhodoquinone (I) was undertaken by us. The synthetic route to rhodoquinone-O $(\mathrm{I}, n=0)$ was shown in Chart 1.

3-Halogeno-4-hydroxy-5-nitrotoluene (III, $\mathrm{X}=\mathrm{Br}$ or $\mathrm{Cl}$ ), prepared from $p$-cresol through halogenation and subsequent nitration, ${ }^{10}$ ) was methylated with $\left(\mathrm{CH}_{3}\right)_{2} \mathrm{SO}_{4}$ and $\mathrm{Na}_{2} \mathrm{CO}_{3}$ in refluxing toluene, thereby 3-bromo-4-methoxy-5nitrotoluene (IV, $\mathrm{X}=\mathrm{Br})$ and 3-chloro-4-methoxy-5-nitrotoluene (IV, $\mathrm{X}=\mathrm{Cl}$ ) were obtained in the yields of 73 and $89 \%$, respectively. Subsequently, reduction of IV, (X $=\mathrm{Br}$ or $\mathrm{Cl}$ ) with zinc dust and $\mathrm{HCl}$ or $\mathrm{SnCl}_{2}$ and $\mathrm{HCl}$ was effectively made, and 3-bromo-4-methoxy-5-aminotoluene $(\mathrm{V}, \mathrm{X}=\mathrm{Br})$ and 3-chloro-4-methoxy-5-aminotoluene $(\mathrm{V}, \mathrm{X}=\mathrm{Cl}$ ) were obtained in 73 and $78 \%$ yields, respectively. The compound $\left(\mathrm{V}, \mathrm{X}=\mathrm{Br}\right.$ ) was oxidized with Fremy's salt ${ }^{11)}$ in an aqueous $\mathrm{KH}_{2} \mathrm{PO}_{4}$ solution at room temperature or with $\mathrm{Na}_{2} \mathrm{Cr}_{2} \mathrm{O}_{7}$ and $\mathrm{H}_{2} \mathrm{SO}_{4}$ in aqueous acetone. After purification using silica gel column chromatography ${ }^{12}$ and subsequent recrystallization, 2-bromo-3-methoxy6-methyl-1,4-benzoquinone (VI, $\mathrm{X}=\mathrm{Br}$ ) melting at $62-63^{\circ}$ was obtained, the yield of which attained $37 \%$ by the former method, while the latter resulted in $20 \%$ yield. $\operatorname{IR}^{\mathbf{1 3})} \boldsymbol{\nu}_{\max }^{\text {Nutiol }} \mathrm{cm}^{\mathbf{- 1}}$ :

10) T. Zincke, Ann., 328, 277 (1903).

11) W. Moser and R.A. Howie, J. Chem. Soc., $(A), 1968,3039$.

12) Silica gel "Wakogel C-200" (Wakojunyaku Co., Ltd.) was used.

13) Infrared (IR) spectra were recorded on a Nihonbunko DS 301. 
1670 and 1653 (benzoquinone). $\mathrm{NMR}^{14)} \tau: 3.62(1 \mathrm{H}$, quartet, ring $\mathrm{H}), 5.88(3 \mathrm{H}$, singlet, $\left.\mathrm{OCH}_{3}\right), 7.93\left(3 \mathrm{H}\right.$, doublet, $\left.\mathrm{CH}_{3}\right)$. 2-Chloro-3-methoxy-6-methyl-1,4-benzoquinone (VI, $\mathrm{X}=$ Cl) melting at $58.5-59.3^{\circ}$ was obtained in the yield of $30 \%$ in an analogous manner starting with the compound $(\mathrm{V}, \mathrm{X}=\mathrm{Cl})$. IR $\nu_{\max }^{\text {Nujial }} \mathrm{cm}^{-1}: 1670$ (benzoquinone).

2-Amino-3-methoxy-6-methyl-1,4-benzoquinone (rhodoquinone-0) (I, $n=0)$ could be successfully synthesized in $25 \%$ yield from $\mathrm{VI}(\mathrm{X}=\mathrm{Br})$ by the following reaction sequence. The reaction of $\mathrm{VI}(\mathrm{X}=\mathrm{Br})$ with $\mathrm{NaN}_{3}$ in $80 \% \mathrm{MeOH}$ at room temperature provided the azide compound, which, without isolation, was reduced with $\mathrm{Na}_{2} \mathrm{~S}_{2} \mathrm{O}_{4}$ to the corresponding azidohydroquinone and, subsequently, the crude product was heated in 1,1,2-trichloroethane or $\mathrm{CHCl}_{3}$ under reflux. The resulting product was submitted to silica gel column chromatography and finally purified by recrystallization from $n$-hexane to afford dark violet needles of $\mathrm{I}(n=0)$ melting at $91^{\circ}\left(\right.$ lit. $\left.{ }^{15)} \mathrm{mp} 91^{\circ}\right)$. IR $v_{\max }^{\text {Nuid }} \mathrm{cm}^{-1}: 3420$ and $3300\left(\mathrm{NH}_{2}\right), 1672$ and 1645 (benzoquinone), $1600(\mathrm{NH})$. NMR $\tau: 3.70(1 \mathrm{H}$, quartet, ring $\mathrm{H}), 5.3\left(2 \mathrm{H}\right.$, broad, $\left.\mathrm{NH}_{2}\right), 6.10(3 \mathrm{H}$, singlet, $\left.\mathrm{OCH}_{3}\right), 8.02\left(3 \mathrm{H}\right.$, doublet, $\left.\mathrm{CH}_{3}\right)$.

Another run starting from the compound $(\mathrm{VI}, \mathrm{X}=\mathrm{Cl})$ under the similar reaction conditon produced only an intractable mixture contaminated with large amount of by-product from which the isolation of $\mathrm{I},(n=0)$ was unsuccessful.

On the other hand, an attempt to obtain $\mathrm{I},(n=0)$ by direct conversion of the bromine atom of $\mathrm{VI}(\mathrm{X}=\mathrm{Br})$ to amino group with $\mathrm{NH}_{3}$ failed, however, the following two substances were obtained. To the solution of $\mathrm{VI}(\mathrm{X}=\mathrm{Br})$ in ether- $\mathrm{MeOH}$ was introduced $\mathrm{NH}_{3}$ gas under cooling and the reaction product was purified by silica gel column chromatography and subsequent recrystallization from petroleum ether-ether, thereby reddish violet needles of 2-bromo3 -amino-6-methyl-1,4-benzoquinone (VII) melting at $152-153.5^{\circ}$ was obtained. The presence of $\mathrm{Br}$ was clearly detected by Beilstein's method. IR $\nu_{\max }^{\text {Nujol }} \mathrm{cm}^{-\mathbf{1}}: 3420$ and $3300\left(\mathrm{NH}_{2}\right), 1638$ and 1645 (benzoquinone), $1580(\mathrm{NH})$. NMR $\tau: 3.51(1 \mathrm{H}$, quartet, ring $\mathrm{H}), 4.6(2 \mathrm{H}$, broad, $\mathrm{NH}_{2}$ ), $7.90\left(3 \mathrm{H}\right.$, doublet, $\mathrm{CH}_{3}$ ) (Fig. 1 and 2).

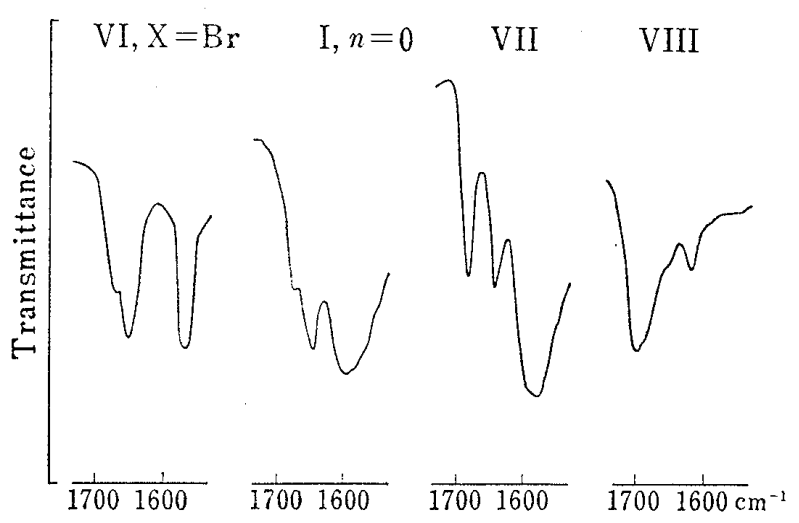

Fig. 1. IR Spectra (Nujol) in $1700-1600 \mathrm{~cm}^{-1}$ Region of VI $(\mathrm{X}=\mathrm{Br})$, I $(n=0)$, VII and VIII

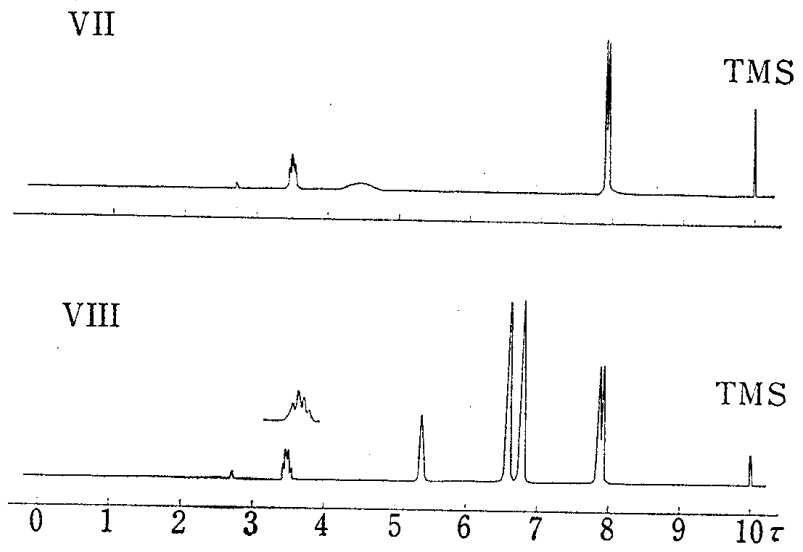

Fig. 2. NMR Spectra of VII and VIII in $\mathrm{CDCl}_{3}$ $(60 \mathrm{Mc})$

The formation of VII should be reasonably interpreted as the result of nucleophilic attack of $\mathrm{NH}_{3}$ on $\mathrm{C}-3$ of $\mathrm{VI}(\mathrm{X}=\mathrm{Br})$. Another crystal was isolated from the concentrate of the mother liquor and purified by recrystallization from petroleum ether to afford pale yellow prisms melting at $80-81^{\circ}$. Its infrared (IR) spectrum showed no absorption band due to $\mathrm{OH}$ group, while absorptions at 2810 and $1700 \mathrm{~cm}^{-1}$ were observed. The former should be ascribable

14) Nuclear magnetic resonance (NMR) spectra were obtained using a Hitachi Perkin-Elmer R-20 and samples were dissolved in $\mathrm{CDCl}_{3}$ containing tetramethylsilane as an internal standard.

15) K. Koshi and M. Shimizu, Chem. Pharm. Bull (Tokyo), 16, 2343 (1968). 
to the $v_{\mathrm{C}-\mathrm{H}}$ of $\mathrm{OCH}_{3}{ }^{16)}$ and the latter to the $v_{\mathrm{C}=0}$ of carbonyl function, which could not be assigned to the benzoquinone carbonyl, since benzoquinone derivatives exhibit ordinarily the band ${ }^{17)}$ near by $1670 \mathrm{~cm}^{-1}$ (Fig. 1), thus indicating that the substance was not possessed of the benzoquinone structure. It was further supported by the ultraviolet (UV) spectrum, ${ }^{18)}$ since this compound had no prominent absorption maximum in the region of $210-340 \mathrm{~m} \mu$ in contrast to the spectra of $I(n=1)$, VI and II $(n=0)$, those exhibited, without exception, the characteristic absorption maxima due to the benzoquinone structure in this region (Fig. 3).

As shown in Fig. 2, its NMR spectrum showed absorption peaks at $\tau 3.45(1 \mathrm{H}$, quartet), $5.35(1 \mathrm{H}$, singlet), $6.60(3 \mathrm{H}$, singlet $), 6.80(3 \mathrm{H}$, singlet $)$ and $7.93(3 \mathrm{H}$, doublet). Signals at $\tau 6.60$ and 6.80 could be assigned to two methoxy groups and it was observed that the resonance at $\tau 7.93$ was coupled with a one proton at 3.45 , suggesting a long range coupling between $\mathrm{CH}_{3}$ and $\mathrm{H}$ in the following moiety: $(\overbrace{\mathrm{O}}^{\mathrm{O}} \mathrm{CH}_{3})$

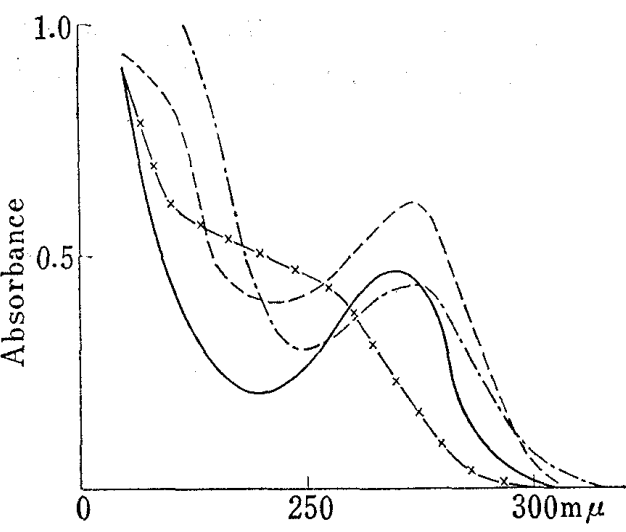

Fig. 3. Ultraviolet Absorption Spectra (in EtOH)

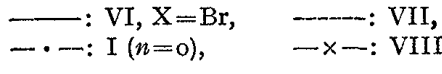

Furthermore, the presence of Br was proved by Beilstein's method. From the above evidence and the data of elemental analysis and molecular weight determination, ${ }^{19)}$ this substance should

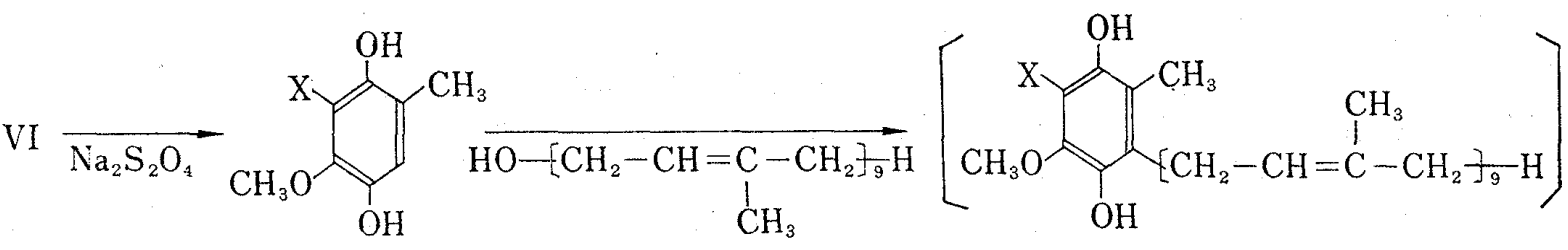

IX

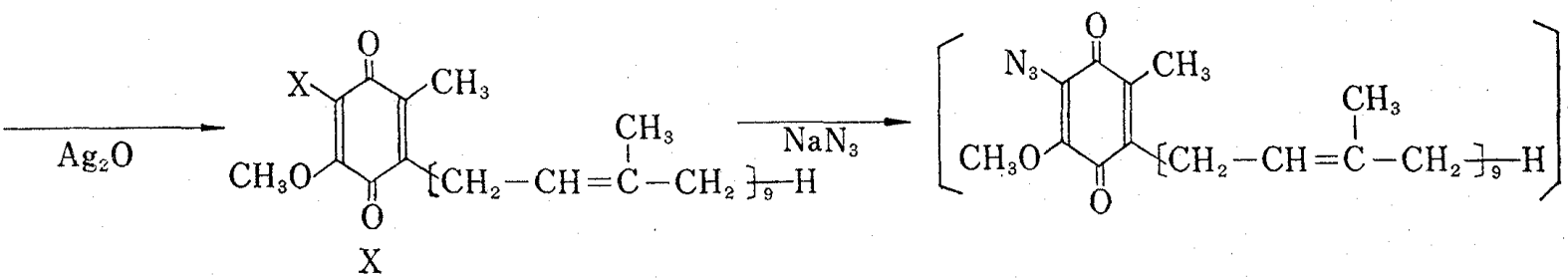

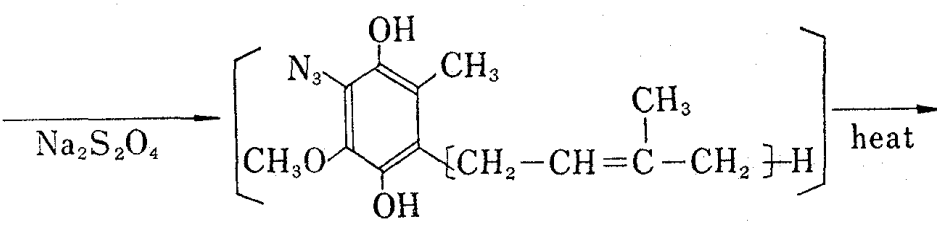

$\mathrm{X}=\mathrm{Br}$ or $\mathrm{Cl}$<smiles>C#CC(C)=CC=C1C(=O)C(C)=C(OC)C(N)C1=O</smiles>

I, $n=9$

Chart 2

16) K. Nakanishi, "IR Absorption Spectroscopy -Practical-," 4th Ed., Nankodo, Tokyo, 1963, p. 42.

17) L.J. Bellamy, "The Infrared Spectra of Complex Molecules," John Willy and Sons, Inc., New York, N. Y., 1964, p. 150.

18) UV spectra were recorded on a Hitachi EPS-2U using EtOH as a solvent.

19) Molecular weight determination was carried out with a Hitachi Perkin-Elmer 115 using EtOH as a solvent. 
be regarded as the cyclohexenedione derivative (VIII), formed by addition of the $\mathrm{CH}_{3} \mathrm{OH}$ molecule to the double bond of $(\mathrm{VI}, \mathrm{X}=\mathrm{Br})$, although the strict structural confirmation still remains to be resolved.

The synthetic scheme of rhodoquinone- $9(\mathrm{I}, n=9)$ was presented in Chart 2.

When 2-bromo-3-methoxy-6-methyl-1,4-hydroquinone (IX, $\mathrm{X}=\mathrm{Br}$ ), prepared almost quantitatively by the reduction of $\mathrm{VI}(\mathrm{X}=\mathrm{Br})$ using $\mathrm{Na}_{2} \mathrm{~S}_{2} \mathrm{O}_{4}$, was condensed with nonaprenyl alcohol (solanesol) in dioxane using $\mathrm{BF}_{3}$. ether as a condensing agent, followed by oxidation of the intermediate hydroquinone with $\mathrm{Ag}_{2} \mathrm{O}$ giving the product which was chromatographed
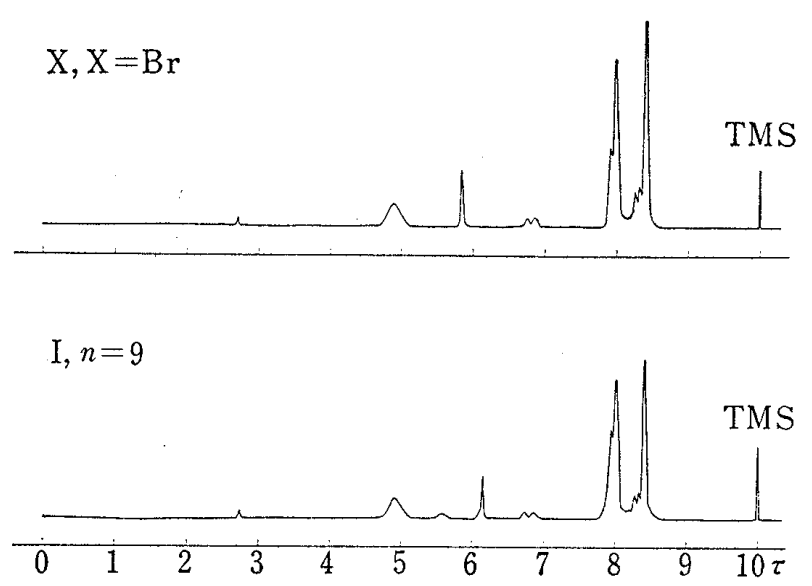

Fig. 4. NMR Spectra of $\mathrm{X},(\mathrm{X}=\mathrm{Br})$ and $\mathrm{I}$ $(n=9)$ in $\mathrm{CDCl}_{3}(60 \mathrm{Mc})$ on an aluminum oxide ${ }^{20)}$ column and further on a silica gel column, thereby a yellow solid was obtained. Recrystallization from ether- $\mathrm{MeOH}$ gave yellow grains of 2-bromo-3-methoxy-5-nonaprenyl-6-methyl-1,4-benzoquinone $(\mathrm{X}, \mathrm{X}=\mathrm{Br})$ melting at $37-39^{\circ}$ in $10 \%$ yield. IR $\nu_{\max }^{\text {Smear }} \mathrm{cm}^{-\mathbf{1}}$ : 1633 (benzoquinone). NMR $\tau: 4.85(9 \mathrm{H}$, multiplet, $-\mathrm{CH}=\mathrm{C}-), 5.83(3 \mathrm{H}$, singlet, $\left.\mathrm{OCH}_{3}\right), 6.8\left(2 \mathrm{H}\right.$, doublet, ring- $\left.\mathrm{CH}_{2}-\right), 7.8-$ $8.1\left(35 \mathrm{H}\right.$, side chain $-\mathrm{CH}_{2}-$ and ring- $\left.\mathrm{CH}_{3}\right)$, $8.26\left(3 \mathrm{H}\right.$, trans ring- $\left.\mathrm{CH}_{2} \mathrm{CH}=\mathrm{C}-\mathrm{CH}_{3}\right), 8.34$ $\left(3 \mathrm{H}\right.$, cis terminal $\left.-\mathrm{CH}=\mathrm{C}-\mathrm{CH}_{3}\right), 8.40(24 \mathrm{H}$, trans $-\mathrm{CH}=\mathrm{C}-\mathrm{CH}_{3}$ ) (Fig. 4).

Since both the signal's intensities at $\tau 8.26$ and 8.34 were almost equal, it should be concluded that the isoprenyl side chain of $\mathrm{X}$ $(\mathrm{X}=\mathrm{Br})$ was of all trans configuration. $\left.{ }^{21}\right)$

Similarly, reaction of the compound ( $\mathrm{IX}, \mathrm{X}=\mathrm{Cl}$ ) with nonaprenyl alcohol followed by oxidation with $\mathrm{Ag}_{2} \mathrm{O}$ and subsequent chromatographic separations yielded 2-chloro-3-methoxy5-nonaprenyl-6-methyl-1,4-benzoquinone $(\mathrm{X}, \mathrm{X}=\mathrm{Cl})$ as a semisolid (15\% yield), IR $\nu_{\max }^{\mathrm{Smar}} \mathrm{cm}^{-\mathbf{1}}$ : 1665 and 1600 (benzoquinone), which was used in the next step without further purification.

Finally, the compound ( $\mathrm{X}, \mathrm{X}=\mathrm{Br}$ or $\mathrm{Cl}$ ) was reacted with $\mathrm{NaN}_{3}$ in ether-MeOH or etheraqueous $\mathrm{MeOH}$ under reflux, thereby the corresponding azido compound was formed which, without isolation, was subjected to reduction with $\mathrm{Na}_{2} \mathrm{~S}_{2} \mathrm{O}_{4}$. The crude hydroquinone, thus obtained, was refluxed in 1,1,2-trichloroethane or $\mathrm{CHCl}_{3}$ under nitrogen and the crude product was purified by silica gel column chromatography and subsequent recrystallization from $\mathrm{MeOH}$ to separate magenta needles of 2-amino-3-methoxy-5-nonaprenyl-6-methyl-1,4-benzoquinone (rhodoquinone-9) (I, $n=9)$ melting at $66-67.5^{\circ} . \quad$ IR $\nu_{\max }^{\mathrm{KBr}} \mathrm{cm}^{-1}: 3450$ and $3320\left(\mathrm{NH}_{2}\right), 1668$ and 1650 (benzoquinone), $1600(\mathrm{NH})$. NMR $\tau: 4.90(9 \mathrm{H}$, multiplet, $-\mathrm{CH}=\mathrm{C}-), 5.4(2 \mathrm{H}$, broad, $\left.\mathrm{NH}_{2}\right), 6.15\left(3 \mathrm{H}\right.$, singlet, $\left.\mathrm{OCH}_{3}\right), 6.90\left(2 \mathrm{H}\right.$, doublet, ring- $\left.\mathrm{CH}_{2}-\right), 8.0\left(35 \mathrm{H}\right.$, side chain $-\mathrm{CH}_{2}-$ and ring- $\left.\mathrm{CH}_{3}\right), 8.28\left(3 \mathrm{H}\right.$, trans ring $\left.-\mathrm{CH}_{2}-\mathrm{CH}=\mathrm{C}-\mathrm{CH}_{3}\right), 8.35\left(3 \mathrm{H}\right.$, cis terminal $\left.-\mathrm{CH}=\mathrm{C}-\mathrm{C}_{3}\right), 8.42$ $\left(24 \mathrm{H}\right.$, trans $-\mathrm{CH}=\mathrm{C}-\mathrm{CH}_{3}$ ) (Fig. 4).

The intensities of two signals at $\tau 8.28$ and 8.35 were almost equal, as those of $\mathrm{X}(\mathrm{X}=\mathrm{Br})$, consequently it could be concluded that the isoprenyl side chain retained all trans configuration.

It was confirmed by IR, NMR spectroscopy and mixed melting point that rhodoquinone-9 $(\mathrm{I}, n=9)$, thus synthesized, was completely identical with the authentic sample from the natural source.

20) Aluminum oxide "Woelm neutral (activity grade I)," deactivated with $7 \%$ of water in $n$-hexane, was used.

21) P. Scheudel, H. Mayer, T. Metzger, R. Rüeg, and O. Isler, Helv. Chim. Acta, 46, 2517 (1963). 


\section{Experimental ${ }^{22)}$}

3-Bromo-4-methoxy-5-nitrotoluene (IV, $\mathrm{X}=\mathrm{Br}$ )-_-2-Bromo-6-nitro-p-cresol (30 g) was well triturated with $42.5 \mathrm{~g}$ of $\mathrm{Na}_{2} \mathrm{CO}_{3}$ in $100 \mathrm{ml}$ of toluene and the suspension was gently refluxed with $33 \mathrm{~g}$ of $\left(\mathrm{CH}_{3}\right)_{2} \mathrm{SO}_{4}$ for $2 \mathrm{hr}$. Additional $\left(\mathrm{CH}_{3}\right)_{2} \mathrm{SO}_{4}(33.5 \mathrm{~g})$ was then added and refluxing was continued for a further $2 \mathrm{hr}$. The cooled reaction mixture was washed with $10 \% \quad \mathrm{Na}_{2} \mathrm{CO}_{3}$ and then water. The organic layer was dried over anhyd. $\mathrm{MgSO}_{4}$, and the solvent was removed in vacuo to leave a yellow solid which was recrystallized from $90 \% \mathrm{MeOH}$ giving $23 \mathrm{~g}(73 \%)$ of $\mathrm{IV}(\mathrm{X}=\mathrm{Br})$ as pale yellow needles, mp 52-53. Anal. Calcd. for $\mathrm{C}_{8} \mathrm{H}_{8} \mathrm{O}_{3} \mathrm{NBr}: \mathrm{C}, 39.05 ; \mathrm{H}, 3.27 ; \mathrm{N}, 5.69$. Found: $\mathrm{C}, 39.16 ; \mathrm{H}, 3.22 ; \mathrm{N}, 5.60$.

3-Chloro-4-methoxy-5-nitrotoluene (IV, $\mathrm{X}=\mathrm{CI}$ )—_A reaction was carried out with $46.5 \mathrm{~g}$ of 2 -chloro6-nitro-p-cresol, $50 \mathrm{~g}$ of $\mathrm{Na}_{2} \mathrm{CO}_{3}$ and $73 \mathrm{~g}$ of $\left(\mathrm{CH}_{3}\right)_{2} \mathrm{SO}_{4}$ in $130 \mathrm{ml}$ of toluene according to the same method as described above. Recrystallization from aqueous $\mathrm{MeOH}$ gave $44.2 \mathrm{~g}(89 \%)$ of $\mathrm{IV}(\mathrm{X}=\mathrm{Cl})$ as pale yellow needles, $\mathrm{mp} 41-41.5^{\circ}$. Anal. Calcd. for $\mathrm{C}_{8} \mathrm{H}_{8} \mathrm{O}_{3} \mathrm{NCl}: \mathrm{C}, 47.66 ; \mathrm{H}, 4.00 ; \mathrm{N}, 6.95$. Found: $\mathrm{C}, 47.52 ; \mathrm{H}, 3.97$; $\mathrm{N}, 6.99$.

3-Bromo-4-methoxy-5-aminotoluene $(\mathrm{V}, \mathrm{X}=\mathrm{Br})-\mathrm{IV}(\mathrm{X}=\mathrm{Br})(40 \mathrm{~g})$ was dissolved in $120 \mathrm{ml}$ of concd. $\mathrm{HCl}$ and $120 \mathrm{ml}$ of $60 \% \mathrm{EtOH}$ at $55^{\circ}$. To this solution was added $43 \mathrm{~g}$ of zinc dust in small portions over $1.5 \mathrm{hr}$. The resultant solution was stirred at $70^{\circ}$ for $2 \mathrm{hr}$. After being basified with $30 \% \mathrm{NaOH}$, the reaction mixture was extracted with ether. The ethereal extract was washed with water and dried over anhyd. $\mathrm{MgSO}_{4}$. Evaporation of the solvent in vacuo gave a dark brown oil of V $(\mathrm{X}=\mathrm{Br})(25 \mathrm{~g}, 73.5 \%)$. $\mathrm{HCl}$ salt (from EtOH): white needles, mp $214^{\circ}$ (decomp.). Anal. Calcd. for $\mathrm{C}_{8} \mathrm{H}_{10} \mathrm{NBr} \cdot \mathrm{HCl}: \mathrm{C}, 38.05$; $\mathrm{H}, 4.39 ; \mathrm{N}, 5.55$. Found: $\mathrm{C}, 37.68 ; \mathrm{H}, 4.42 ; \mathrm{N}, 5.35$.

3-Chloro-4-methoxy-5-aminotoluene $(\mathrm{V}, \mathrm{X}=\mathrm{Cl}$ )—A solution of $39.2 \mathrm{~g}$ of $\mathrm{IV}(\mathrm{X}=\mathrm{Cl})$ and $96 \mathrm{~g}$ of $\mathrm{SnCl}_{2} \cdot 2 \mathrm{H}_{2} \mathrm{O}$ in a mixture of $165 \mathrm{ml}$ of concd. $\mathrm{HCl}$ and $240 \mathrm{ml}$ of EtOH was heated under reflux. Dry $\mathrm{HCl}$ gas was slowly passed through the solution. After $3.5 \mathrm{hr}$, the passage of gas was stopped and refluxing was continued for a further $2 \mathrm{hr}$. The residue from evaporation of the solvent was basified with $30 \% \mathrm{NaOH}$ and the reaction mixture was extracted with ether. After working up in a similar manner as described above, there was obtained $26 \mathrm{~g}(78 \%)$ of $\mathrm{V}\left(\mathrm{X}=\mathrm{Cl}\right.$ ) as a dark brown oil. $\mathrm{HCl}$ salt (from EtOH- $\left.\mathrm{H}_{2} \mathrm{O}\right)$ : white flakes, $\mathrm{mp} 185-200^{\circ}$ (sublimation). Anal. Calcd. for $\mathrm{C}_{8} \mathrm{H}_{10} \mathrm{ONCl} \cdot \mathrm{HCl}: \mathrm{C}, 46.17 ; \mathrm{H}, 5.32 ; \mathrm{N}, 6.76$. Found: $\mathrm{C}, 45.90 ; \mathrm{H}, 5.24 ; \mathrm{N}, 6.54$.

2-Bromo-3-methoxy-6-methyl-1,4-benzoquinone (VI, $\mathbf{X}=\mathbf{B r}$ )_-a) To a stirred solution of $28 \mathrm{~g}$ of potassium nitrosodisulfonate in $470 \mathrm{ml}$ of $0.17 \mathrm{M}$ aqueous $\mathrm{KH}_{2} \mathrm{PO}_{4}$ solution and $1400 \mathrm{ml}$ of water was added $8.8 \mathrm{~g}$ of $\mathrm{V}(\mathrm{X}=\mathrm{Br})$ in $150 \mathrm{ml}$ of ether in one portion. The resultant solution was stirred at room temperature for $6 \mathrm{hr}$, and then extracted with ether. Evaporation of the solvent gave a crude liquid of $\mathrm{VI}(\mathrm{X}=\mathrm{Br})$ which was purified by chromatography on silica gel $(100 \mathrm{~g})$. Elution with $n$-hexane-ether $(95: 5)$ gave a yellow solid. Recrystallization from petroleum ether yielded $2.7 \mathrm{~g}(37.6 \%)$ of $\mathrm{VI}(\mathrm{X}=\mathrm{Br})$ as orange yellow needles, mp 62-63․ Anal. Calcd. for $\mathrm{C}_{8} \mathrm{H}_{7} \mathrm{O}_{3} \mathrm{Br}: \mathrm{C}, 41.59 ; \mathrm{H}, 3.05$. Found: $\mathrm{C}, 41.87 ; \mathrm{H}, 3.04$. Further elution with $n$-hexane-ether $(3: 2)$ afforded $1.2 \mathrm{~g}$ of $\mathrm{V}(\mathrm{X}=\mathrm{Br})$.

b) To a stirred suspension of $9 \mathrm{~g}$ of $\mathrm{V}(\mathrm{X}=\mathrm{Br})$ in a mixture of $30 \mathrm{ml}$ of acetone and $100 \mathrm{ml}$ of $30 \%$ $\mathrm{H}_{2} \mathrm{SO}_{4}$ was added dropwise a solution of $14.7 \mathrm{~g}$ of $\mathrm{Na}_{2} \mathrm{Cr}_{2} \mathrm{O}_{7}$ in $80 \mathrm{ml}$ of water over $2 \mathrm{hr}$ under cooling below $-5^{\circ}$. The reaction mixture was stirred for a further $2 \mathrm{hr}$ at $-5^{\circ}$. After being allowed to stand overnight in ice-box, the solution was extracted with petroleum ether, and the organic layer was washed with water and dried over anhyd. $\mathrm{MgSO}_{4}$. After removal of the solvent in vacuo, the residue was chromatographed over silica gel $(40 \mathrm{~g})$. After working up in a similar manner as described above, there was obtained $2.1 \mathrm{~g}$ $(21.5 \%)$ of $\mathrm{VI}(\mathrm{X}=\mathrm{Br})$ as orange yellow needles, $\mathrm{mp} 62-63^{\circ}$.

2-Chloro-3-methoxy-6-methyl-1,4-benzoquinone (VI, $\mathrm{X}=\mathrm{Cl}$ ) $-\mathrm{A}$ suspension of $15 \mathrm{~g}$ of $\mathrm{V}(\mathrm{X}=\mathrm{Cl})$ in $30 \mathrm{ml}$ of acetone and $125 \mathrm{ml}$ of $30 \% \mathrm{H}_{2} \mathrm{SO}_{4}$ was treated with a solution of $17.5 \mathrm{~g}$ of $\mathrm{Na}_{2} \mathrm{Cr}_{2} \mathrm{O}_{7}$ in $100 \mathrm{ml}$ of water under a similar condition as described in $\mathrm{b})$ of $\mathrm{VI}(\mathrm{X}=\mathrm{Br})$. Recrystallization from petroleum ether gave $5 \mathrm{~g}(30.6 \%)$ of $\mathrm{VI}(\mathrm{X}=\mathrm{Cl})$ as orange yellow needles, mp 58.5-59.3 . Anal. Calcd. for $\mathrm{C}_{8} \mathrm{H}_{7} \mathrm{O}_{3} \mathrm{Cl}$ : $\mathrm{C}, 51.49 ; \mathrm{H}, 3.78$. Found: $\mathrm{C}, 51.57 ; \mathrm{H}, 3.73$.

2-Bromo-3-methoxy-6-methyl-1,4-hydroquinone (IX, X=Br)-A solution of $\mathrm{VI}(\mathrm{X}=\mathrm{Br})$ in $20 \mathrm{ml}$ of ether was reduced by shaking with saturated aqueous $\mathrm{Na}_{2} \mathrm{~S}_{2} \mathrm{O}_{4}$ solution until the solution became colorless. The organic layer was separated and dried over anhyd. $\mathrm{MgSO}_{4}$. Evaporation of the solvent gave a solid which was recrystallized from $n$-hexane to separate colorless needles of IX $(\mathrm{X}=\mathrm{Br})$ in almost quantitative

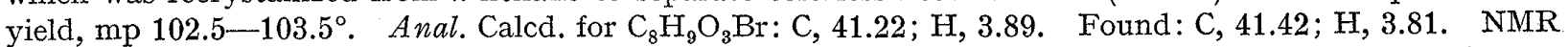
$\tau: 3.22(1 \mathrm{H}$, singlet, ring- $\mathrm{H}), 4.70(1 \mathrm{H}$, singlet, $\mathrm{OH}), 4.78(1 \mathrm{H}$, singlet, $\mathrm{OH}), 6.14\left(3 \mathrm{H}\right.$, singlet, $\left.\mathrm{OCH}_{3}\right), 7.77$ $\left(3 \mathrm{H}\right.$, singlet, $\left.\mathrm{CH}_{3}\right)$.

2-Chloro-3-methoxy-6-methyl-1,4-hydroquinone (IX, $\mathrm{X}=\mathrm{Cl}$ )—An experiment was carried out essentially by the same method as described above. Recrystallization from petroleum ether-ether gave colorless.

22) Melting points are uncorrected and were obtained with a micro melting point apparatus (Yanagimoto, MP-S2). 
plates in almost quantitative yield, $\mathrm{mp} 108.5-109.5^{\circ}$. Anal. Calcd. for $\mathrm{C}_{8} \mathrm{H}_{9} \mathrm{O}_{3} \mathrm{Cl}: \mathrm{C}, 50.94 ; \mathrm{H}, 4.81$. Found: $\mathrm{C}, 51.06 ; \mathrm{H}, 4.82$.

2-Amino-3-methoxy-6-methyl-1,4-benzoquinone $(\mathrm{I}, \boldsymbol{n}=\mathbf{0})$ _ $\mathrm{VI}(\mathrm{X}=\mathrm{Br})(100 \mathrm{mg})$ and $50 \mathrm{mg}$ of $\mathrm{NaN}_{3}$ in $5 \mathrm{ml}$ of $80 \% \mathrm{MeOH}$ were stirred at room temperature for $1 \mathrm{hr}$. During this time, the solution became deep red. The mixture was extracted with $10 \mathrm{ml}$ of $\mathrm{CHCl}_{3}$ and the extract was shaken with saturated aqueous $\mathrm{Na}_{2} \mathrm{~S}_{2} \mathrm{O}_{4}$ solution until the organic layer changed from red to colorless. The $\mathrm{CHCl}_{3}$ layer was separated and dried over anhyd. $\mathrm{MgSO}_{4}$. To this solution was added $5 \mathrm{ml}$ of 1,1,2-trichloroethane and the resultant solution was refluxed under nitrogen for $5 \mathrm{hr}$. Evaporation of the solvent in vacuo gave the crude $(\mathrm{I}, n=0)$ which was dissolved in a small amount of $n$-hexane-ether $(4: 1)$ and transferred to a column of silica gel $(10 \mathrm{~g})$. Elution with $n$-hexane-ether $(98: 2)$ gave a brown solid, which was not investigated. Further development of the column with $n$-hexane-ether $(95: 5)$ gave traces of impurities, and the violetcolored band was finally eluted with $n$-hexane-ether $(9: 1)$ to afford I $(n=0)$ as a solid. Recrystallization from $n$-hexane yielded $18 \mathrm{mg}(24.8 \%)$ of dark violet needles, mp $91^{\circ}$. Anal. Calcd. for $\mathrm{C}_{8} \mathrm{H}_{9} \mathrm{O}_{3} \mathrm{~N}$ : C, 57.45 ; $\mathrm{H}, 5.42 ; \mathrm{N}, 8.38$. Found: $\mathrm{C}, 57.38 ; \mathrm{H}, 5.37 ; \mathrm{N}, 8.51$.

Reaction of Ammonia with (VI, $\mathbf{X}=\mathbf{B r}$ ) - A solution of $340 \mathrm{mg}$ of VI ( $\mathrm{X}=\mathrm{Br}$ ) in a mixture of $50 \mathrm{ml}$ of ether and $20 \mathrm{ml}$ of $\mathrm{MeOH}$ was stirred under cooling below $0^{\circ}$ and dry $\mathrm{NH}_{3}$ gas was introduced thereto during $15 \mathrm{~min}$. Stirring was continued for a further $15 \mathrm{~min}$ and the resulting mixture was concentrated in vacuo. The residue was taken up in a small portion of ether and chromatographed over silica gel (5g). Elution with $n$-hexane-ether $(95: 5)$ afforded $70 \mathrm{mg}$ of the starting material. Further development of the column with $n$-hexane-ether $(85: 15)$ gave a violet solid which was recrystallized from petroleum etherether to separate $50 \mathrm{mg}$ of VII as reddish violet needles, mp 152-153.5. Anal. Calcd. for $\mathrm{C}_{7} \mathrm{H}_{6} \mathrm{O}_{2} \mathrm{NBr}$ : $\mathrm{C}, 38.91 ; \mathrm{H}, 2.80 ; \mathrm{N}, 6.48$. Found: $\mathrm{C}, 39.12 ; \mathrm{H}, 2.78 ; \mathrm{N}, 6.59$. The mother liquor was concentrated in vacuo to yield a solid. Recrystallization from petroleum ether gave yellow prisms of VIII $(100 \mathrm{mg}), \mathrm{mp}$ $80-81^{\circ}$. TLC $\left.{ }^{23}\right)\left[\mathrm{CHCl}_{3}\right]$ : single spot, $R f=0.57$. Anal. Calcd. for $\mathrm{C}_{9} \mathrm{H}_{11} \mathrm{O}_{4} \mathrm{Br}: \mathrm{C}, 41.08 ; \mathrm{H}, 4.12 ; \mathrm{N}, 0$; mol. wt., 263. Found: C, 41.39; H, 4.17; N, 0; mol. wt, ${ }^{19)} 267$.

2-Bromo-3-methoxy-5-nonaprenyl-6-methyl-1,4-benzoquinone ( $\mathrm{X}, \mathrm{X}=\mathrm{Br})-\mathrm{IX}(\mathrm{X}=\mathrm{Br})(1.0 \mathrm{~g})$ and $0.5 \mathrm{ml}$ of $\mathrm{BF}_{3}$. ether were dissolved in $2 \mathrm{ml}$ of absol. dioxane under nitrogen at $55-60^{\circ}$ (bath temperature). To this solution was dropped $1.8 \mathrm{~g}$ of solanesol in $0.8 \mathrm{ml}$ of absol. dioxane over $1 \mathrm{hr}$ and the mixture was then heated with stirring at $60-65^{\circ}$ for $1 \mathrm{hr}$. The cooled reaction mixture was diluted with $50 \mathrm{ml}$ of petroleum ether and the petroleum ether solution was extracted well four times with $75 \% \mathrm{MeOH}(20 \mathrm{ml}$ each). The $\mathrm{MeOH}$ layer was re-extracted with petroleum ether. The combined petroleum ether extract was washed with water and dried over anhyd. $\mathrm{MgSO}_{4}$. After removal of the solvent in vacuo, the residue was dissolved in ether, and the resultant solution was oxidized with $3 \mathrm{~g}$ of $\mathrm{Ag}_{2} \mathrm{O}$ at room temperature for $1.5 \mathrm{hr}$. The inorganic material was filtered off, and the filtrate gave the crude $\mathrm{X}(\mathrm{X}=\mathrm{Br})$ which was dissolved in a small amount of $n$-hexane and charged on a column of aluminum oxide $(50 \mathrm{~g})$ and developed with $n$-hexane and $n$-hexane-ether $(98: 2)$ successively. The elute with $n$-hexane-ether was evaporated in vacuo to give X ( $\mathrm{X}=\mathrm{Br})$ as a yellow semi-solid which was dissolved in $n$-hexane and re-chromatographed on silica gel (50 g). Elution with $n$-hexane-ether $(98: 2)$ gave a yellow oil, which failed to crystallize and was not investigated. Further development of the column with $n$-hexane-ether $(97: 3)$ yielded $400 \mathrm{mg}$ of $\mathrm{X}(\mathrm{X}=\mathrm{Br})$. Recrystallization from ether-MeOH afforded $150 \mathrm{mg}(10.4 \%)$ of yellow grains, $\mathrm{mp} 37-39^{\circ}$. TLC $\left(\mathrm{CHCl}_{3}-n\right.$-hexane (4:1)): single spot, $R f=0.86$. Anal. Calcd. for $\mathrm{C}_{53} \mathrm{H}_{79} \mathrm{O}_{3} \mathrm{Br}: \mathrm{C}, 75.41 ; \mathrm{H}, 9.43$. Found: $\mathrm{C}, 75.49 ; \mathrm{H}, 9.39$. The above $\mathrm{MeOH}$ layer was poured into water $(500 \mathrm{ml})$ and the solution was extracted with ether followed by oxidation with $\mathrm{Ag}_{2} \mathrm{O}$ to give $0.4 \mathrm{~g}$ of $\mathrm{VI}(\mathrm{X}=\mathrm{Br})$.

2-Chloro-3-methoxy-5-nonaprenyl-6-methyl-1,4-benzoquinone $(\mathrm{X}, \mathrm{X}=\mathrm{Cl})$ - -To a stirred solution of $2.4 \mathrm{~g}$ of IX $(\mathrm{X}=\mathrm{Cl})$ and $0.3 \mathrm{ml}$ of $\mathrm{BF}_{3} \cdot$ ether in $10 \mathrm{ml}$ of absol. dioxane, $4.1 \mathrm{~g}$ of solanesol in $4 \mathrm{ml}$ of absol. dioxane was dropped over $2 \mathrm{hr}$ under nitrogen at $50-55^{\circ}$ (bath temperature). The reaction mixture was then heated at $55-60^{\circ}$ for a further $1 \mathrm{hr}$. After working up in a similar manner as described above, there was obtained $650 \mathrm{mg}(15 \%)$ of $\mathrm{X}(\mathrm{X}=\mathrm{Cl})$ as a semi-solid. The recovery of VI $(\mathrm{X}=\mathrm{Cl})$ from the MeOH layer was $1.4 \mathrm{~g}$.

2-Amino-3-methoxy-5-nonaprenyl-6-methyl-1,4-benzoquinone (I, $n=9)-$-a) A solution of $50 \mathrm{mg}$ of $\mathrm{X}(\mathrm{X}=\mathrm{Br})$ and $25 \mathrm{mg}$ of $\mathrm{NaN}_{3}$ in a mixture of $3 \mathrm{ml}$ of ether and $2 \mathrm{ml}$ of $\mathrm{MeOH}$ was refluxed under nitrogen for $5 \mathrm{hr}$ and the solvent was evaporated in vacuo. The residue was dissolved in $10 \mathrm{ml}$ of ether and reduced by shaking with saturated $\mathrm{Na}_{2} \mathrm{~S}_{2} \mathrm{O}_{4}$ solution until the resultant solution changed from red to coorless. The residue from the ethereal layer was taken up into $5 \mathrm{ml}$ of $1,1,2$-trichloroethane and the solution was refluxed under nitrogen for $2 \mathrm{hr}$. After removal of the solvent in vacuo, the residue was dissolved in small amounts of $n$-hexane, and the solution was poured on a column of silica gel $(10 \mathrm{~g})$, developed with $n$-hexane, $n$-hexaneether $(98: 2)$ and $n$-hexane-ether $(95: 5)$ successively. The violet-colored band was finally eluted with $n$-hexane--ether (92.5:7.5). A solid obtained from the elute was recrystallized from $\mathrm{MeOH}$ to yield $10 \mathrm{mg}$

23) TLC was carried out using silica gel G (E. Merck AG.) plates having a $1 \mathrm{~mm}$ layer. The plates were dried at room temperature overnight and activated for $3 \mathrm{hr}$ at $80^{\circ}$. Spots were detected by iodine vapour. 
$(21.6 \%)$ of $\mathrm{I}(n=9)$ as magenta needles, $\mathrm{mp} 66-67.5^{\circ} . \quad \mathrm{TLC}\left[\mathrm{CHCl}_{3}\right]:$ single spot, $\mathrm{Rf}=0.5$. Anal. Calcd. for $\mathrm{C}_{53} \mathrm{H}_{81} \mathrm{O}_{3} \mathrm{~N}: \mathrm{C}, 81.59 ; \mathrm{H}, 10.47 ; \mathrm{N}, 1.80$. Found: $\mathrm{C}, 81.97 ; \mathrm{H}, 10.48 ; \mathrm{N}, 1.49$.

b) A solution of $350 \mathrm{mg}$ of $\mathrm{X}(\mathrm{X}=\mathrm{Cl})$ and $100 \mathrm{mg}$ of $\mathrm{NaN}_{3}$ in a mixture of $10 \mathrm{ml}$ of ether and $5 \mathrm{ml}$ of $80 \% \mathrm{MeOH}$ was refluxed under nitrogen for $5 \mathrm{hr}$ and the resulting mixture was treated with ether. The ethereal layer was reduced by shaking with saturated aqueous $\mathrm{Na}_{2} \mathrm{~S}_{2} \mathrm{O}_{4}$ solution until the resulting solution became essentially colorless. The organic layer was separated and dried over anhyd. $\mathrm{MgSO}_{4}$. The residue obtained upon removal of the solvent was dissolved in $15 \mathrm{ml}$ of $\mathrm{CHCl}_{3}$ and the solution was refluxed under nitrogen for $2 \mathrm{hr}$. The following procedure was the same as described above. Recrystallization from $\mathrm{MeOH}$ gave $75 \mathrm{mg}(21.8 \%)$ of $\mathrm{I}(n=9)$ as magenta needles, mp $66.5-67.5^{\circ}$, which was identical with the sample obtained in a) in all respects.

Acknowledgement The authors wish to express their thanks to F. Hoffmann-LaRoche and Co., Ltd., Basel, Switzerland, for generous supply of solanesol, and to Dr. S. Natori, National Institute of Hygienic Sciences, for precious gift of rhodoquinone- 9 and copies of the spectral data and also for his helpful advice and criticism. Thanks are also due to Mr. S. Uehara, Executive Vice President, Dr. S. Ikawa, Executive Director, and Dr. I. Tanaka, Director of this laboratory, for their encouragement. 